\title{
CORRIGENDA
}

\section{Genome-wide supported variant MIR 137 and severe negative symptoms predict membership of an impaired cognitive subtype of schizophrenia}

MJ Green, MJ Cairns, J Wu, M Dragovic, A Jablensky, PA Tooney, RJ Scott and VJ Carr on behalf of the Australian Schizophrenia Research Bank

Molecular Psychiatry (2013) 18, 843; doi:10.1038/mp.2013.48; published online 30 April 2013

Correction to: Molecular Psychiatry advance online publication, 26 June 2012; doi:10.1038/mp.2012.84

Following publication of the above article, it came to the authors' attention that they had incorrectly referred to the minor allele (G) carriers in the study sample as 'risk genotypes,' with respect to putative risk for schizophrenia. However, according to the genome-wide association study reported by Ripke et al., ${ }^{5}$ it is the major (T) allele that shows association with schizophrenia caseness. The error appears in the Results section in two places: under 'MIR137 genotype' (second sentence) and under 'Prediction of GoM-derived clinical phenotypes' (last sentence).

\section{Genome-wide association study of obsessive-compulsive disorder}

SE Stewart, D Yu, JM Scharf, BM Neale, JA Fagerness, CA Mathews, PD Arnold, PD Evans, ER Gamazon, L Osiecki, L McGrath, S Haddad, J Crane, D Hezel, C Illman, C Mayerfeld, A Konkashbaev, C Liu, A Pluzhnikov, A Tikhomirov, CK Edlund, SL Rauch, R Moessner, P Falkai, W Maier, S Ruhrmann, H-J Grabe, L Lennertz, M Wagner, L Bellodi, MC Cavallini, MA Richter, EH Cook Jr, JL Kennedy, D Rosenberg, DJ Stein, SMJ Hemmings, C Lochner, A Azzam, DA Chavira, E Fournier, H Garrido, B Sheppard, P Umaña, DL Murphy, JR Wendland, J Veenstra-Vander Weele, D Denys, R Blom, D Deforce, F Van Nieuwerburgh, HGM Westenberg, S Walitza, K Egberts, T Renner, EC Miguel, C Cappi, AG Hounie, M Conceição do Rosário, AS Sampaio, H Vallada, H Nicolini, N Lanzagorta, B Camarena, R Delorme, M Leboyer, CN Pato, MT Pato, E Voyiaziakis, P Heutink, DC Cath, D Posthuma, JH Smit, J Samuels, OJ Bienvenu, B Cullen, AJ Fyer, MA Grados, BD Greenberg, JT McCracken, MA Riddle, Y Wang, V Coric, JF Leckman, M Bloch, C Pittenger, V Eapen, DW Black, RA Ophoff, E Strengman, D Cusi, M Turiel, F Frau, F Macciardi, JR Gibbs, MR Cookson, A Singleton for the North American Brain Expression Consortium, J Hardy for the UK Brain Expression Database, AT Crenshaw, MA Parkin, DB Mirel, DV Conti, S Purcell, G Nestadt, GL Hanna, MA Jenike, JA Knowles, N Cox and DL Pauls

Molecular Psychiatry (2013) 18, 843; doi:10.1038/mp.2013.15; published online 12 February 2013

Correction to: Molecular Psychiatry advance online publication, 14 August 2012; doi:10.1038/mp.2012.85

The name of coauthor LK Davis was omitted from the author line. Dr Davis should have been listed as the tenth author (between ER
Gamazon and L Osiecki). Her affiliation is as follows: Department of Medicine, University of Chicago, Chicago, IL, USA. 